\title{
Perancangan dan Pembuatan Aplikasi Untuk Mengukur Efektivitas Produksi Berdasarkan Permintaan Pelanggan Dengan Metode Radial Basis Function
}

\author{
Bagus Sayekti Sujatmiko \\ Program Studi Sistem Informasi \\ Institut Informatika Indonesia \\ BagusBayekGilbert@gmail.com
}

\author{
Hermawan Andika \\ Program Studi Teknik Informatika \\ Institut Informatika Indonesia \\ andika@ikado.ac.id
}

\author{
Timothy John Pattiasina \\ Program Studi Sistem Informasi \\ Institut Informatika Indonesia \\ temmy@ikado.ac.id
}

\begin{abstract}
Abstrak - Model jaringan saraf fungsi radial basis ( Radial Basis Function $=$ RBF $)$ adalah model jaringan saraf yang memiliki unit lapisan tersembunyi, dimana fungsi aktivasinya menggunakan fungsi basis (Gaussian) dan fungsi linear pada lapisan output. Untuk mendapatkan hasil fungsi RBF terbaik, diperlukan kombinasi yang tepat antara jumlah input data dan jumlah node (clustering).

Penelitian ini dilakukan diperusahaan kimia yang bergerak dibidang produksi deterjen. Data yang akan diproses diperoleh dari transaksi perusahaan yang sudah dilakukan selama 2 tahun sebelumnya untuk dijadikan sebagai data training dan data testing. Pada data training dilakukan pengelompokan data dan pencarian nilai sentroid menggunakan metode K-Means kemudian dilanjutkan perhitungan RBF sampai menghasilkan nilai bobot training. Hasil bobot training digunakan untuk proses pengujian data testing hingga menghasilkan suatu prediksi produksi berupa nilai similarity. Nilai similarity tertinggi akan digunakan untuk perhitungan prediksi produksi pada aplikasi user. Hasil dari penelitian ini berupa nilai prediksi produksi yang akan digunakan untuk membantu proses pengambilan keputusan dan pemenuhan permintaan pelanggan. Dari percobaan yang sudah dilakukan diperoleh akurasi nilai similarity diatas $90 \%$.
\end{abstract}

Kata Kunci : Metode Radial Basis Function (RBF), KMeans, Data Training, Data Testing.

\section{PENDAHULUAN}

Salah satu permasalahan yang dihadapi oleh sebuah perusahaan penghasil produk adalah memprediksi jumlah produk yang akan dijadikan acuan target produksi. Hasil produksi dalam waktu dan jumlah yang tepat akan mendatangkan keuntungan bagi perusahaan tersebut. Oleh sebab itu penggunaan metode prediksi yang tepat akan sangat membantu perusahaan dalam mengukur seberapa efektif jumlah produksi barang yang mereka hasilkan. Salah satu metode yang dipakai dalam penelitian metode prediksi untuk menentukan target produksi yaitu metode jaringan saraf Radial Basis Function (RBF).

PT. X adalah sebuah perusahaan kimia yang bertempat di Surabaya dan didirikan pada tahun 2010. Perusahaan ini bergerak di bidang produksi detergent, homecare dan kimia pembersih dengan fokus menghasilkan berbagai terobosan baru dalam dunia kimia pembersih, yaitu, produk dengan formula terinovatif di kelasnya, namun dapat dikonsumsi dengan harga yang terjangkau tanpa mengurangi kualitas produk. Perusahaan ini memproduksi berbagai macam bahan kimia mentah dan diproses menjadi barang jadi seperti detergent, homecare, dan kimia pembersih. Kegiatan produksi yang dilakukan setiap harinya membuat perusahaan ini mendatangkan bahan kimia dari berbagai pemasok untuk diproses menjadi barang jadi. Dalam setiap bulannya perusahaan ini membutuhkan pasokan bahan baku dalam jumlah yang tidak menentu. Hal ini disebabkan karena berbagai macam faktor yang mempengaruhi kebutuhan akan bahan baku tersebut seperti pemintaan pelanggan akan produk tertentu.

Jumlah pembelian bahan baku yang dilakukan oleh perusahaan PT. X ini tidak menentu, dikarenakan jenis produk yang dihasilkan memiliki bahan baku yang berbeda. Semua bahan baku yang baru diterima dari pemasok mengalami proses pendataan dan seleksi. Semua bahan dasar berasal dari bahan-bahan kimia yang tersedia. Beberapa hasil produksi seperti deterjen tidak bisa bertahan dalam waktu yang lama sedangkan permintaan dari pelanggan yang diterima oleh perusahaan jumlahnya tidak menentu, sehingga perusahaan sering kali melakukan pembelian bahan baku dan melakukan proses produksi yang berlebihan. Hal ini mengakibatkan perusahaan mengalami penumpukan bahan baku dan barang jadi di gudang. Dengan berbagai macam kendala tersebut maka perusahaan ingin mengelola produksi menjadi lebih efisien, serta dapat mengontrol jumlah stok barang menjadi lebih efisien guna mengurangi resiko kerugian.

Berdasarkan permasalahan tersebut, maka penulis mencoba untuk membantu memberikan solusi pemecahan 
masalah dengan cara membuat aplikasi dengan metode Radial Basis Function (RBF). Pemilihan metode RBF sebagai salah satu metode dari Jaringan Syaraf Tiruan (JST) didalam penelitian ini dikarenakan metode RBF dapat digunakan untuk pengenlan sebuah karakter sederhana, serta semakin banyak penelitian yang bertujuan untuk meningkatkan hasil pelatihan JST RBF dengan cara optimasi bobot hasil pelatihan JST RBF. Penelitian sejenis yang sudah pernah dilakukan adalah prediksi produksi panen kelapa sawit dengan memanfaatkan metode RBF pada tahun 2015 [1].

\section{METODOLOGI PENELITIAN}

\section{A. Data}

Data adalah segala fakta, angka, atau teks yang dapat diproses atau kumpulan informasi yang diperoleh dari suatu pengamatan, dapat berupa angka, lambang atau sifat yang berarti bahwa data itu sesuatu yang diketahui atau dianggap. Dalam penggunaan sehari-hari data berarti suatu pernyataan yang diterima secara apa adanya. Pernyataan ini adalah hasil pengukuran atau pengamatan suatu variabel yang bentuknya dapat berupa angka, kata-kata, atau citra. Dalam keilmuan (ilmiah), fakta dikumpulkan untuk menjadi data. Data kemudian diolah sehingga dapat diutarakan secara jelas dan tepat sehingga dapat dimengerti oleh orang lain yang tidak langsung mengalaminya sendiri, hal ini dinamakan deskripsi. Pemilahan banyak data sesuai dengan persamaan atau perbedaan yang dikandungnya dinamakan klasifikasi.

\section{B. Informasi}

Informasi adalah pola, asosiasi atau hubungan antara semua data yang dapat memberikan informasi. Pengertian lain tentang informasi yaitu data yang telah diproses dengan sedemikian rupa menjadi bentuk yang memiliki arti bagi penerima dan dapat berupa fakta yang memiliki suatu nilai yang bermanfaat. Jadi ada suatu proses transformasi data menjadi suatu informasi sama dengan input - proses output. Dalam ilmu komputer, informasi adalah data yang disimpan, diproses atau ditransmisikan. Para ahli meneliti konsep informasi sebagai pengetahuan yang didapatkan dari pembelajaran, pengalaman atau instruksi.

Hal mengenai kualitas informasi tergantung dari 3 hal, yaitu informasi harus:

a. Akurat, berarti informasi harus bebas dari kesalahan kesalahan dan tidak bisa atau menyesatkan. Akurat juga berarti informasi harus jelas mencerminkan maksudnya.

b. Tetap pada waktunya, berarti informasi yang datang pada penerima tidak boleh terlambat.

c. Relevan, berarti informasi tersebut mempunyai manfaat untuk pemakainya. Relevansi informasi untuk tiap - tiap orang satu dengan yang lainnya berbeda.

Secara umum informasi adalah data yang sudah diolah menjadi suatu bentuk lain yang lebih berguna yaitu pengetahuan atau keterangan yang ditujukan bagi penerima dalam pengambilan keputusan, baik masa sekarang atau yang akan datang. Untuk memperoleh informasi yang berguna, tindakan yang pertama adalah mengumpulkan data, kemudian mengolahnya sehingga menjadi informasi.

\section{Starling}

Jaringan Syaraf Tiruan (JST) merupakan salah satu metode yang dapat digunakan untuk melakukan klasifikasi [2]. Jaringan syaraf berbasis radial biasanya membutuhkan neuron lebih banyak jika dibanding dengan jaringan feedforward. Jaringan ini akan berkerja lebih baik apabila data input yang diberikan cukup banyak. Pada jaringan RBF ini, input akan diolah oleh fungsi aktivasi buka merupakan hasil penjumlahan terbobot dari data input, namun berupa vektor jarak antara vektor bobot dan vector input yang dikalikan dengan bobot bias. Dengan berkembangnya penelitian, muncul beberapa penelitian yang bertujuan meningkatkan akurasi hasil pelatihan JST RBF dengan cara optimasi bobot hasil pelatihan JST RBF. Berikut ini topologi milik RBF terdiri dari layer input unit, layer-hidden unit, layer output unit. Topologi RBF digambarkan sebagai berikut:

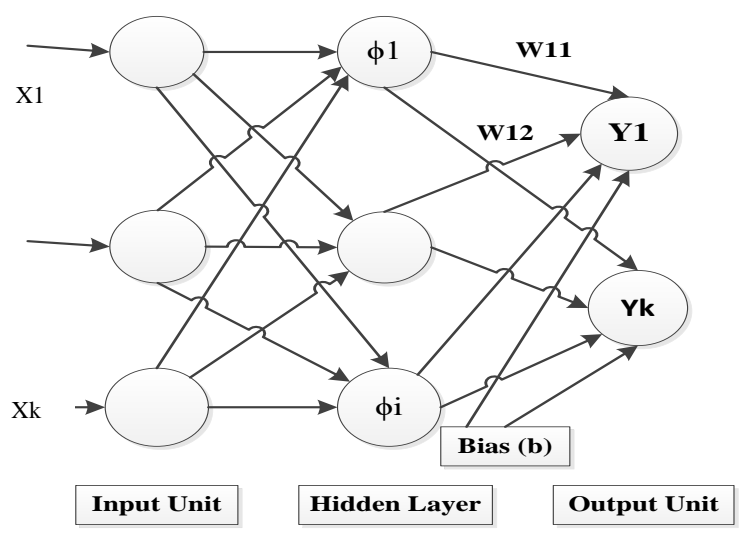

Gambar 1. Topologi Radial Basis Function Network.

Hal yang khusus pada RBF ialah :

1. Pemrosesan sinyal dari input layer ke hidden layer, sifatnya non-linear, sedangkan dari hidden layer ke output layer sifatnya linear.

2. Pada hidden layer digunakan sebuah fungsi aktivasi yang berbasis radial misalnya Gaussian.

3. Pada output unit, sinyal dijumlahkan seperti biasa.

4. Sifat jaringannya ialah feed-forward.

Fungsi Gaussian bisa dituliskan sebagai berikut :

$$
\begin{gathered}
\varphi(\mathrm{r})=\exp \left(-\frac{r^{2}}{2 \sigma^{2}}\right) \quad \sigma>0 \\
\sigma=\frac{d_{\max }}{\sqrt{m_{1}}}
\end{gathered}
$$

Dimana: $\sigma \quad=$ nilai spread

$\mathrm{d}_{\text {max }}=$ Jarak maksimum antara dua pusat

$m_{1}=$ Titik tengah 
Nilai spread menentukan bagaimana data tersebar. Jika nilai spread makin besar, maka sensitifitas antar data semakin berkurang. Pada rumus juga disebutkan tentang adanya center atau pusat. Pusat yang dimaksud disini ialah pusat cluster dari data. Jumlah center mnentukan jumlah hidden unit yang dipakai.

Selain fungsi Gaussian, fungsi aktivasi yang lain yang berbasis radial yang biasa diterapkan adalah sebagai berikut:

1. Multi-Quadric Functions

$$
\phi(r)=\left(r^{2}+\sigma^{2}\right)^{1 / 2}
$$$$
\text { Parameter } \sigma>0
$$

2. Generalized Multi-Quadric Functions

$$
\begin{aligned}
& \phi(r)=\left(r^{2}+\sigma^{2}\right)^{\beta} \\
& \text { Parameter } \sigma>0,1>\beta>0
\end{aligned}
$$

3. Inverse Multi-Quadric Functions

$$
\phi(r)=\left(r^{2}+\sigma^{2}\right)^{-1 / 2}
$$

Parameter $\sigma>0$

4. Generalized Inverse Multi-Quadric Functions

$$
\begin{aligned}
& \phi(r)=\left(r^{2}+\sigma^{2}\right)^{-\alpha} \\
& \text { Parameter } \sigma>0,1>\quad \alpha>0
\end{aligned}
$$

5. Thin Plate Spline Function

$$
\phi(r)=r^{2} \ln (r)
$$

6. Cubic Function

$$
\phi(r)=r^{3}
$$

7. Linear Function

$$
\phi(r)=r
$$

RBF biasa digunakan untuk menyelesaikan 2 jenis permasalahan yaitu pattern classification dan time series modeling. Untuk jenis masalah classification fungsi aktivasi yang biasa digunakan ialah fungsi Gaussian, sedangkan untuk jenis masalah time series modeling fungsi aktivasi yang biasa digunakan ialah fungsi thin-plate spline.

\section{ANALISA DAN DESAIN SISTEM}

Berbagai macam data yang sudah diperoleh dapat dijadikan sebagai input untuk diolah menggunakan metode Radial Basis Function. Semakin banyak jumlah data yang diperoleh maka semakin banyak data input training yang akan dipakai. Semakin banyak sistem menerima data input training maka akan semakin baik sistem menghasilkan output yang berupa hasil akhir untuk prediksi proses produksi. Hasil dari data yang sudah diproses akan dipilih kemudian dilakukan pengujian. Pengujian dilakukan dengan cara mencari jarak kemiripan dari output yang dihasilkan oleh sistem dengan output yang sebenarnya dengan cara mengambil sampling untuk data training sebesar $70 \%$ dan data testing $30 \%$ [3].

\section{A. Proses Perhitungan Metode Radial Basis Function}

Proses ini dilakukan pertama kali dengan cara memasukan semua data transaksi perusahaan (pembelian bahan baku, transaksi penjualan, stok persediaan bahan baku yang tersedia, dan stok persediaan barang jadi yang tersedia) ke dalam file Excel. Proses ini sangat penting karena akan mempengaruhi nilai output/hasil dari aplikasi yang akan dibuat. Jika proses pemasukan data mengalami kesalahan maka akan berdampak pada nilai yang dihasilkan. Aplikasi yang dibuat dinyatakan berhasil jika hasil output aplikasi ini mengalami kemiripan dengan keadaan yang sebenarnya.

Tabel 1. Data percobaan Produk Softener

\begin{tabular}{cccccccc}
\hline $\mathbf{X 1}$ & $\mathbf{X 2}$ & $\mathbf{X 3}$ & $\mathbf{X 4}$ & $\mathbf{X 5}$ & $\mathbf{X 6}$ & $\mathbf{X 7}$ & Гarget \\
\hline 0,75 & 0,032 & 0,2976 & 1 & 1 & 0,3863 & 0,3399 & ), 1353 \\
\hline 0,75 & 0,65 & 0,2871 & 0,9904 & 0,9733 & 0,3551 & 0,2985 & ), 1230 \\
\hline 0,75 & 0,0967 & 0,2819 & 0,9761 & 0,9564 & 0,3135 & 0,2571 & ), 1107 \\
\hline 0,75 & 0,129 & 0,2778 & 0,9713 & 0,9458 & 0,2476 & 0,2571 & ), 0984 \\
\hline
\end{tabular}

Tahap 1: Menentukan Nilai Sentroid Yang didapat Menggunakan Metode K-Means.

$\mathrm{T} 1=[0,75 ; 0,65 ; 0,2871 ; 0,9904 ; 0,9733 ; 0,3551 ; 0,2985]$

$\mathrm{T} 2=[0,75 ; 0,0859 ; 0,2857 ; 0,9824 ; 0,9674 ; 0,3158 ; 0,2847]$

Nilai spread diasumsikan sebagai $\sigma=1$

Contoh data testing diatas hanya hanya untuk 1 (satu) produk barang yaitu produk Softener (FS-01). Data tersebut sudah mengalami proses normalisasi data.

Tahap 2: Pembaharuan Bobot

Langkah 1: Meneruskan sinyal ke hidden layer dan menghitung nilai fungsi aktivasi. Fungsi yang digunakan adalah fungsi Gaussian.

Langkah 2: Membentuk matriks Gaussian.

$G=\left[\begin{array}{ccc}0,680092 & 0,987644 & 1 \\ 1 & 0,726118 & 1 \\ 0,733372 & 0,99894 & 1 \\ 0,751324 & 0,992106 & 1\end{array}\right]$

hasil dari pembentukan matriks eksponen, kemudian dilakukan transpose matriks dari matriks eksponen. Berikut ini hasil matriks transposenya:

$G^{T}=\left[\begin{array}{cccc}0,680092337 & 1 & 0,733372 & 0,751324 \\ 0,987644261 & 0,726118 & 0,99894 & 0,992106 \\ 1 & 1 & 1 & 1\end{array}\right]$

Langkah 3: Menghitung Pseudoinvers dari matriks Gaussian.

$$
G^{T} G=\left[\begin{array}{ccc}
2,564846932 & 2,875794 & 3,164788 \\
2,875794264 & 3,484844 & 3,704808 \\
3,164787733 & 3,704808 & 4,0000
\end{array}\right]
$$


$\left(G^{T} G\right)^{-1}=\left[\begin{array}{ccc}296,9252 & -308,0123 & -520,2080 \\ 308,0123 & 338,2249 & -556,9630 \\ -520,2080 & -556,9630 & 927,6973\end{array}\right]$

$d=\left(\begin{array}{c}0,1353 \\ 0,1230 \\ 0,1107 \\ 0,0984\end{array}\right) \quad W=\left(\begin{array}{c}W_{1} \\ W_{2} \\ b\end{array}\right)$

$G^{T} d=\left(\begin{array}{c}0,370130993 \\ 0,431146666 \\ 0,4674\end{array}\right)$

$W=\left(G^{T} G\right)^{-1} G^{T} d=\left(\begin{array}{c}-0,44549 \\ -0,49506 \\ 0,927853\end{array}\right)$

Jadi, $W_{1}=-0,44549 ; W_{2}=-0,49506$ dan bias $=0,927853$

Langkah 4: Mencoba mengetahui output dari jaringan. Sesuai rumus, output dari jaringan adalah:

$$
Y=W_{1} * \varphi_{1}+W_{2} * \varphi_{2}+\text { bias }
$$

Tabel 2. Testing Produksi

\begin{tabular}{cccccc}
\hline $\mathbf{W 1}$ & $\mathbf{p 2}$ & $\mathbf{W 2}$ & Bias & $\mathbf{Y}$ & Target \\
\hline$-0,4454$ & 0,9876 & $-0,4950$ & 0,9278 & 0,1358 & 0,1353 \\
\hline$-0,4454$ & 0,7261 & $-0,4950$ & 0,9278 & 0,1229 & 0,1230 \\
\hline$-0,4454$ & 0,9989 & $-0,4950$ & 0,9278 & 0,1086 & 0,1107 \\
\hline$-0,4454$ & 0,9921 & $-0,4950$ & 0,9278 & 0,0999 & 0,0984 \\
\hline
\end{tabular}

Jika pada tabel menunjukkan hasil perhitungan (Y) dari prediksi menggunakan RBF sama dengan target maka testing dinyatakan berhasil. Demikian sebaliknya jika hasil perhitungan (Y) tidak sama (perbandingan dibawah 70\%) maka testing dinyatakan gagal.

\section{B. Metode Cosine Similarity}

Salah satu metode yang digunakan untuk menghitung similaritas adalah dengan menggunakan metode Cosine Similarity[4]. Cosine Similarty digunakan untuk menghitung dua/lebih vektor dokumen. Jika d1 dan d2 adalah dua vektor dokumen maka similaritas antara dua vektor dokumen yang dihitung dengan rumus Cosine Similarity adalah sebagai berikut:

$$
\operatorname{Cos}(d 1, d n)=\frac{(d 1 \bullet d n)}{\|d 1\|\|\mid d n\|}
$$

Dimana:

$(\mathrm{d} 1 \bullet \mathrm{d} 2)$ adalah vector dot product

||d || adalah panjang vector $\mathrm{d}$.
Simililaritas mempunyai beberapa sifat :

$\mathrm{S}(\mathrm{p}, \mathrm{q})=1$ (or maximum similarity) only if $\mathrm{p}=\mathrm{q}$

$\mathrm{S}(\mathrm{p}, \mathrm{q})=\mathrm{S}(\mathrm{q}, \mathrm{p})$ for all $\mathrm{p}$ and $\mathrm{q}$.

(Symmetry) dimana $\mathrm{S}(\mathrm{p}, \mathrm{q})$ merupakan similaritas antara titiktitik (objek data), $\mathrm{p}$ dan $\mathrm{q}$

Hasil nilai bobot dari perhitungan RBF yang dilakukan sebelumnya, akan dilanjutkan perhitingan menggunakan rumus Cosine Similarity. Berikut ini 4 vektor yang dihasilkan dari perhitungan RBF sebelumnya: $\mathrm{d} 1=0,135841 ; 0,122929 ; 0,10865 ; 0,09998$ $\mathrm{d} 2=0,1353 ; 0,1230 ; 0,1107 ; 0,0984$

Proses perhitungan:

$\mathrm{d} 1 \cdot \mathrm{d} 2 \cdot \mathrm{d} 3 \cdot \mathrm{d} 4=(0,135841 * 0,1353)+(0,1229290 * 0,1230)+$ $(0,10865 * 0,1107 *)+(0,099980,0984)=0,055342$

$\|\mathrm{d} 1\|=(0,135841 * 0,135841)+(0,122929 * 0,122929)+(0,10865 *$ $0,10865)+(0,09998 * 0,09998)=0,235248938$

$\|\mathrm{d} 2\|=(0,1353 * 0,1353)+(0,1230 * 0,1230)+(0,1107 * 0,1107)$ $+(0,0984 * 0,0984)=0,235312$

$$
\operatorname{Cos}(d 1, d 2)=\frac{0,055342063}{(0,235248938 * 0,235312856}=0,9997283708
$$

Jika dijadikan persen (\%) adalah $0,9997283708 \times 100 \%=$ 99,97283708\%

Karena hasil dari perhitungan Cosine Similarity sangat baik, maka nilai minimum, nilai maksimum, sentroid dari data training dan nilai bobot serta nilai bias yang dihasilkan dari proses testing akan disimpan. Nilai minimum, nilai maksimum, sentroid, nilai bobot, dan nilai bias yang disimpan akan digunakan untuk perhitungan proses prediksi produksi pada form prediksi produksi. Sebagai contoh terdapat permintaan pelanggan pada bulan 5, tanggal 10 , untuk produk softener sebanyak 140 , persediaan barang jadi sebanyak 40, persediaan bahan baku Ecosol N $702 \mathrm{U}$ sebanyak $40 \mathrm{~kg}$, Parfume sebanyak $20 \mathrm{~kg}$ dan Nipaguard sebanyak $30 \mathrm{~kg}$. Berikut ini proses perhitungan permintaan pelanggan yang terjadi pada form prediksi produksi:

Nilai Minimum:

[ $0 ; 0 ; 10,340825 ; 1,57895 ; 15 ; 0 ; 66 ; 0]$

Tabel 3. Contoh Permintaan Pelanggan

\begin{tabular}{cccccccc}
\hline BIn & Tgl & Ecosol & $\begin{array}{c}\text { Nipa } \\
\text { guard }\end{array}$ & Parfume & $\begin{array}{c}\text { Per- } \\
\text { minta- } \\
\text { an }\end{array}$ & $\begin{array}{c}\text { Per- } \\
\text { sedia- } \\
\text { an }\end{array}$ & $\begin{array}{c}\text { Pro } \\
\text { duksi }\end{array}$ \\
\hline 5 & 10 & 40 & 20 & 15 & 140 & 40 & $?$ \\
\hline
\end{tabular}

Nilai Maksimum:

[ $12 ; 31 ; 34,87119 ; 171,57895 ; 39,21053 ; 500 ; 414 ; 200$ ]

Sentroid:

$\mathrm{T} 1=[0,75 ; 0,65 ; 0,2871 \quad ; 0,9904 ; 0,9733 ; 0,3551 \quad ;$

$0,2985]$

$\mathrm{T} 2=[0,75 ; 0,0859 ; 0,28576 ; 0,98246 ; 0,9674 ; 0,3158 ; 0,2847]$ 
Nilai Bobot $\left(\mathrm{W}_{1}\right):-0,44549$

Nilai Bobot $\left(\mathrm{W}_{2}\right)$ : $-0,49506$

Nilai Bias: 0,927853

Proses Normalisasi Data:

[ 0,$416667 ; 0,322581 ; 0,18994 ;-0,09649 ; 0,28 ;-0,0747]$

Matriks:

$[0,11743 ; 0,12875]$

Prediksi (Y):

$\mathrm{Y}=(0,11743 *-0,44549)+(0,12875 *-0,49506)+0,927853$ $=0,81180$

Denormalisasi data $=(\mathrm{Y} *$ Maksimum Produksi $)-(\mathrm{Y} *$ Nilai Minimum Produksi $)+$ Minimum Produksi

$$
\begin{aligned}
& =(0,81180 * 200)-(0,81180 * 0)+0 \\
& =162,3600
\end{aligned}
$$

Jadi, pada bulan 5 tanggal 10 untuk produk softener dengan bahan baku Ecosol sebanyak $40 \mathrm{Kg}$, Nipaguarg 20 $\mathrm{Kg}$, dan Parfume $15 \mathrm{Kg}$, dengan permintaan sebanyak 140 pcs dan persediaan sebanyak 40 maka prediksi produksi sebanyak 162 pcs.

\section{KESIMPULAN DAN SARAN}

Dalam pembuatan aplikasi efektivitas produksi berdasarkan permintaan pelanggan dengan menggunakan metode Radial Basis Function ini penulis dapat mengambil beberapa kesimpulan antara lain:

- Melalui aplikasi ini, maka dapat membantu pemilik memaksimalkan produksi. Persediaan bahan baku yang ada, banyaknya permintaan pelanggan dan persediaan barang diinputkan kedalam aplikasi kemudian diproses sampai menghasilkan prediksi produksi. Hasil akhir dari aplikasi ini akan memberikan informasi prediksi produksi terhadap permintaan pelanggan.

- Hasil informasi berupa prediksi produksi terhadap permintaan pelanggan dari aplikasi yang telah dikembangkan akan membantu pemilik perusahaan untuk menanggulangi peningkatan dan penurunan permintaan dari pelanggan. Hal ini dapat dilakukan apabila pemilik perusahaan memasukkan data jumlah permintaan pelanggan dan perkiraan jumlah bahan baku pada bulanbulan tertentu.

- Informasi dari prediksi produksi yang dihasilkan oleh aplikasi ini, dapat membantu pemilik perusahaan dalam pengambilan keputusan penentuan jumlah produksi barang.

- Kualitas data yang diproses mempengaruhi nilai kemiripan hasil prediksi prouksi, serta jumlah kluster yang ditetapkan akan mempengaruhi lamanya waktu yang diperlukan dalam pemrosesan data.

- kualitas data transaksi yang diproses mempengaruhi nilai kemiripan hasil akhir dari prediksi. Jika kualitas data yang proses baik/valid maka hasil dari prediksi akan mendekati nilai dari data sebenarnya. Demikian sebaliknya, jika data yang diproses kurang bailk/valid maka prosentase nilai hasil prediksi jauh dari data sebenarnya.

\section{REFERENSI}

[1] Jannati, R. (2015). Prediksi Produksi Panen Kelapa Sawit Menggunakan Jaringan Syaraf Tiruan Radial Basis Function (RBF). Medan: FIKOMTI USU.

[2] Kusumadewi, S. (2004). Membangun Jaringan Syaraf Tiruan Menggunakan MATLAB dan Excel Link. Yogyakarta: Graha Ilmu.

[3] Prasetyo, E. (2012). Data Mining: Konsep dan Aplikasi menggunakan MATLAB. Yogyakarta: ANDI.

[4] Setiawan, K. Paradigma Sistem Cerdas. Jakarta: PT. Gramedia. 